\title{
Politics, Violence, and Victimization in Margaret Atwood's Selected Novels
}

\author{
Elaheh Soofastaei, Sayyed Ali Mirenayat \\ Faculty of Modern Languages and Communication \\ Universiti Putra Malaysia \\ E-mail address: ela.soofastaei@yahoo.com, ali.mirenayat@yahoo.com
}

Keywords: Politics; Victimization; Female protagonist; Survival; Violence; Suppression

\begin{abstract}
Canadian novels have witnessed a movement from description to more different analytical and interpretative directions. Margaret Atwood's oeuvres are belonged to the postmodern literary field of feminist writing. Her fictions show a severe alertness of the relationship between chains and slavery, i.e. between women's requirement for relationships with others and her requirements for freedom and autonomy. In this paper, The Handmaid's Tale, Bodily Harm, Surfacing, and The Edible Woman will be surveyed in a direct relationship between politics, violence and victimization of female protagonists. An examination on Margaret Atwood's novels demonstrates that she is pioneer in the dimension of time by being a revolter against the patriarchal society.
\end{abstract}

\section{INTRODUCTION}

Most of Atwood's novels fight against the politics and genders. She portrays the silent and concealed functions of gender. She discovers her real potential with the resist to complete her desires and requirements. Survival is a key word for Margaret Atwood and she wants her protagonist to reject to be a victim and her need for equal space like a man. Her feminist view is neither male-centered nor female-centered but it proposes a new idea on women's problems.

Atwood's novels are filled with characters that are all looking for equilibrium, liberty, vengeance, and success (The Many Faces of Margaret Atwood, 2001). Female Characters of this "feminist writer," on the surface, move from defenseless little girls to murderesses. All Atwood's fictions are written in meticulous style. We can see Margaret Atwood's feminist voice in her writings in which female protagonist is a portrayal of "every women" who is victimized and minimized by gender and politics. Atwood's stories' characteristics display a struggle for possession of themselves and their bodies because the female body itself is mainly ownership by pregnancy, rape, and so on. She frequently represents her protagonists as territories of male gender, immigrants, intruders, strangers even on their own place.

\section{POLITICS AS SUPPRESSION}

The Handmaid's Tale surveys the results which paying no attention to acts of political cruelty can have in its description of American society at some point in a fundamentalist autocracy, known as the Republic of Gilead. The alterations that create the foundation of the Republic of Gilead is ingenious but continuing, and therefore not being watched by most people, as Offred, the protagonist, puts in plain words:

"We lived, as usual, by ignoring ... Nothing changes instantaneously. . . There were stories in the newspapers, of course, corpses in ditches or the woods . . but they were about other women, and the men who did such things were other men." (p.32).

The Handmaid's Tale demonstrates that the lack of confrontation has made a society in which women live in panic and most women die in advance. According to MacAlpine, Individuality is essential to fight in opposition to victimization without the result being separation from the rest of 
society. (The Many Faces of Margaret Atwood, 2001) If victimization cannot all the time be sensibly avoided, if the cost of hostility greatly is more important than the advantages, in that case an effectual agreement must be discovered. Gilead is a communication established in old-style values and masculinity functions and on the suppression of women by men. Women in Gilead are not only allowed to read or write but also prohibited to vote.

Gilead is a land that second marriage regard as an adultery. In Gilead government women are adulterous who doesn't have any right to educate their children. As Atwood shows us only officials of Gilead are commanders that if their handmaids give birth they have promotion. Painful world that she creates is cold and insipid world, insipid and even sometimes terrible and the pain is felt only at the end of the book. Atwood is always interested in surveying Totalitarian and Fascist regimes and the roots of this book back to her learning for sure.

In this communication the most important thing is women's inner physicality. The storyteller has "viable ovaries", and that is what survived her and somewhat out of threat all this moments. But society looks her simple container with ovaries who is ending date is emerging as soon as she gives birth. Women are separated in different classes based on household tasks and are recognized with their uniforms in Gilead society.

Offred regards herself "a distorted shadow, a parody of something, some fairytale figure in red cloak" ( HT 19) due to of hazardous low reproduction rates, Handmaids are allocated to carry children for privileged couples and this kind of suppression makes a communication with women who are considered as subhuman. The handmaids are considered as nothing more than creatures with functional ovaries and a womb in which they are decreased to their productiveness. Gilead looks for to dispossess women of their independence to make them obedient bearers of the following generation. "We are two legged wombs that are all: sacred vessels" (HT-146) Offred remarks "there are only women who are fruitful and women who are barren this is the law" (HT57).

There are some restrictions for women in Gilead, for instance freedom of speech is legitimately forbidden in there and considered an unlawful act for them. Women are not allowed to use ordinary language; they are considered a formal vocabulary that pays no attention to reality only for communicating with their leaders. Although for Offred was different in parts of story. For instance, when Offred's leader permits her to read and plays with him, she understood his mean to her. In fact, they were doing "kinky", a kind of sexual act. "Now it is forbidden for us now it is dangerous. It is indecent" (HT-149). This kind of behavior impact on handmaids' psyche and caused to accept system and a good reason for the infringements against them. Offred changed her idea and looked at this obvious crime as a simple ritual. Jane Gardam argues:

"There is even a horrible beauty in the heroine's plight her quiet reverie of better days, her dignity, her sorrow, her courageous rationing of recollection of times past so that she will be able to bear them." (Balachandran 152).

\section{VIOLENCE AND FEMALE PROTAGONISTS}

Surveying on Margaret Atwood's Bodily Harm and The Handmaid's Tale, show that both protagonists (Rennie in Bodily Harm and Offred in The Handmaid's Tale) are about to thirteenyear-old and it is illustrated by the writer to discover how they react to 'oppression in all its functions, both physical and psychological'. Atwood in her works, including fiction and nonfiction focus on the conflict between men and women. 'Who can do what to whom and get away with it.' She only wants to show the male violence against women which seems to have been done very well...'to counterbalance women's recent self-assertion'. This self-assertion is comprehensible when we take women's growth in recent decades although this isn't completely true in Rennie. However, male's manners, as mentioned in the stories, take on a frightening characteristic. Things seem to turn into really desperatation for Rennie when she moves to see her tormenter is separately from herself as well. Bodily Harm highlights the opportunity of free, particularly female character. 
What is important to Atwood's oeuvres is the usual portrait of women's complexities in protecting themselves. Atwood turns from psychological violence in town living to physical violence on a large scale in Bodily Harm and The Handmaid's Tale. Women in Bodily Harm who lives on a pair of island are treated like dogs. A husband may kill his wife without punishment, living situations are loathsome, and women don't have anywhere to go and have a little hope for a future.

The protagonist, who looks the islands from Toronto, slowly recognizes how bad the condition is. Finally, she is imprisoned with a woman whom considers being a prostitute. While the two women grow up in prison, the protagonist finds out in relation to what love and sacrifice are, but the price of these words is high. She and the women in island did not have any chance to regain their fate; they were entrapped by situations. They had no option but to admit whatever violence was formed against them.

The Handmaid's Tale demonstrates women behaved worse than the women in Bodily Harm. In Bodily Harm, it is a disaster that women die by violent means. In The Handmaid's Tale, it is a grace if they die too soon. They are kept in steady horror of being suspended or sent to regions of high radiation where cancer is an inevitable (Dorthy Jones, "Waiting for the Rescue: A Discussion of Margaret Atwood's Bodily Harm"). Many are allowed to be alive only as long as they can reproduce. The women in Bodily Harm and The Handmaid's Tale cannot avoid physical violence. It demonstrates how defenseless women are in danger of violence. For instance, a possible escape from repression is punishment in both novels.

While physical violence is completely unacceptable against women, the answers will be found during Atwood's working to change society's outlook toward women. Atwood's novels do this by demonstrating how society undervalues women on an everyday basis in both large and small issues. Murder is unacceptable in Canada, so novels like Bodily Harm and The Handmaid's Tale, which show great violence; do not oblige the reader to inspect matters that are faced often in Canadian life. Atwood recognizes that many agreements must be made if independent women are remaining alive, but that survival involves conflict.

\section{VICTIMIZATION AND SURVIVAL REQUIREMENTS}

Victimization, especially for female protagonist is at the core of each Atwood's works. Atwood uses her characters to show how survival requirements identify and then refuse victimization. In Atwood's second novel, Surfacing, the central character brings to a closes her narrative with "This above all, to refuse to be a victim" (S 206). When this novel started, its protagonist did not recognize that she was a victim. Atwood displays in her novels that women are systemically distinguished because of the society, and because, this victimization is constant, many women do not recognize how they are being affected.

Atwood does not suggest amazing solution to victimization, but she proposes that identification of victimization authorizes a person to work toward its prevention. Recognition of victimization requires analyzing society from the edge, away from the majority point of view. This 'consciousness raising' needs creativity, especially; creativity to investigate the world, see it in a dissimilar light, and recognize that society harms women.

Atwood employs her novels to battle victimization by 'raising consciousnesses'. The protagonist of Surfacing investigates the negative response of social consistency, to the degree that at one point she hides and bears on an island, in the shrub. In another word, if one were to admit all victimization, one could not to stay alive. Victimization can be decreased by using power. Victimization in Atwood's novels only infrequently gets the form of physical strength and is never introduced as a fight between good and evil. Victimization results from attack constantly made on female resistance.

In Bodily Harm victimization is significantly gone faster when women are lack of power. In a society like the pre-Gilead society of The Handmaid's Tale, also there is increase of the possibility of a quick decline of female situation. In The Edible Woman, female protagonist in her engagement party feels uncomfortable for the reason that he imagines that Peter influenced her smartly and 
made her an instrument in his hands. She identified her loss of identity and her edibility to Peter. Her feeling of victimization becomes sensitive after she talks with Joe. He says:

"She gets the idea she has a mind, her professors paying attention to what she has to say, they treat Marian like a thinking human being; when she gets married, her core get invaded....her core.....the center of her personality, the thing she's built up, her image of herself....her feminine role and her core are really in opposition. Her feminine role demands passivity from her" (235).

Now Marian believes that she is a poor girl and senses depressed about future. She figures out both Peter and Duncan wanted to utilize and consume her. In fact it was somehow the procedure of victimization in her view. This new consciousness gives her a renovated force and an idea in life. She refuses her passivity and rejects to be a victim. The cake, which Marian bakes and eats, shows the development of her vision and her refusal to be a victim. Marian claims that she cannot be controlled by the people like Peter and Duncan. Marian with loss of individuality is specified by the silencing of the internal self and her refusal of food is caused by her unconscious refusal of the victim role (acceptance of the fact of being consumed and incorporated by peter.) It is Duncan who tells her incapability to eat to an internal revolt, "you are probably representative of modern youth, rebelling against the system" (192). This refutation of the victim role stays on the night of her engagement party. There she escapes from Peter's party and runs away being hunted down by the Peter (photographer/hunter) with his flashgun. Now Marian attempts to make a new image of her. Duncan persists on her making her personal results while Marian discovers that, "her image was taking shape" (267).

This points out to her new personality, as a creative non-victim. Baking a woman shaped cake as a picture of her previous self as a victim- the edible woman for man's use. She drives out all the previous victim factors from inside her and schemes them on her aesthetic formation that is cakewoman. The immobility imposed on the victim role has slowly drained here. The procedure of making the cake is enjoyable as she identifies her own participation in her previous victimization. Marian says: "you look delicious "....very appetizing and that is what will happen to you, that is what you get for being food" (270).

\section{CONCLUSION}

Nevertheless, these three novels are used as instances of the possible results of the collapse of women's rights. They are not first and foremost instances of how such collapse is achieved. Atwood's novels demonstrate how everyday life slowly wears women down. Town living and its intrinsic corruption cause mental and physical violence against women. The protagonists in Atwood's novels effort to understand why they are displeased with the world around them. They find out that they are being victimized, and try to see to the problem. Some hardly move beyond recognizing of victimization, others would not hesitate to refuse, and some of them fail, but most endure. The protagonists are not usual champions. They do not do any unexpected achievements. They are women who reject to admit what is offered them. They do what they can to fight victimization.

\section{References}

[1] Atwood, Margaret. Second Words: Selected Critical Prose. Toronto: Anansi, 1982,333.

[2] Atwood, Margaret. Survival: A Thematic Guide to Canadian Literature. Toronto: Anansi, 1972, 33.

[3] Atwood, Margaret. "A Reply", Signs: Journals of Women in Culture and Society 2, No. 2, $1976,34$.

[4] Atwood, Margaret. The Handmaid's Tale. London: Vintage, 1996

[5] Atwood, Margaret. Bodily Harm. New York: Simon and Schuster, 1981.

[6] Atwood, Margaret. The Edible Woman. Boston: Little Brown, 1969. 
[7] Atwood, Margaret. The Handmaid's Tale. New York: Anchor Books, 1998.

[8] Atwood, Margaret. Surfacing. New York: Simon and Schuster, 1972.

[9] Beauvior, Simone de. The Second Sex, trans. H.M. Parshley. England: Penguin Books, 1972, 295.

[10]Calvalcanti, Ildney. "Utopias of/f Language in Contemporary Feminist Literary Dystopias." Utopian Studies 11.2 (2000), 152-181.

[11]Cooke, Nathalie. Margaret Atwood: A Critical Companion. Westport: Greenwood Press, 2004.

[12]Frye, Northrop. "Varieties of Literary Utopias." Utopias and Utopian Thought.

[13]Gilligan, Carol.. In A Different Voice. Psychological Theory and Women's Development. Cambridge (USA) and London (UK): Harvard University Press. 1983.

[14] Gilman, Charlotte Perkins. Herland. 1915. New York: Pantheon Books, 1979.

[15]Jones, Dorthy. "Waiting for the Rescue: A Discussion of Margaret Atwood's Bodily Harm", Kunapipi, 6.3, 1984, 91.

[16] MacAlpine, Rachel - The Many Faces of Margaret Atwood, 2001. 